\title{
Why was Tao Lujia so willing and swift to greenlight the Red Flag Canal Project in 1960? The instance and his motivations
}

\author{
Ying Chen ${ }^{1}$ Wei-Ning Xiang ${ }^{2}$
}

Received: 1 August 2020 / Accepted: 10 August 2020 / Published online: 9 September 2020

(c) Springer Nature Singapore Pte Ltd. 2020

\begin{abstract}
In an extraordinarily willing and swift fashion, the top leader of Shanxi Province in China, Tao Lujia [陶鲁笳, (1917-2011)], gave permission to the Red Flag Canal project in 1960. Why was he so willing and swift to greenlight a project that would divert water from his home province to benefit the people in a neighbor province? We explored this question through a bipartite investigation. First, we dug into the empirical literature, the literature based on experience and/or observation, in search of his motivations for the action. Second, for a more systematic, deeper understanding, we examined the instance via a lens of compassion practice, an eclectic collection of theoretical constructs on compassion practice through which one can examine an individual's behavior and performance for new insights. This article reports the first part of our research. Its sequel Why was Tao Lujia so willing and swift to greenlight the Red Flag Canal Project in 1960? New insights via a lens of compassion practice reports the second part and is also published in this journal. Both articles are part of the SEPR miniseries on the Red Flag Canal, one of the best kept secrets in the world history of socio-ecological practice.
\end{abstract}

Keywords The Red Flag Canal · China · Tao Lujia (陶鲁笳) · Yang Gui (杨贵) · History of socio-ecological practice

\section{The 1960 greenlight for the Red Flag Canal project: a critical step forward}

On February 6, 1960, Yang Gui [杨贵, (1928-2018)], the Party Secretary of Linxian County (林县) in Henan Province, China, ${ }^{1}$ wrote in his diary:

Today our water diversion project received the greenlight from the Shanxi provincial government. This is a rare window of opportunity, and we should get right on with the project. Otherwise, our Linxian people would have to endure the hardships of water shortage forever. [cited by Wang and Sang (1995, p. 32); English translation by the authors of this article ${ }^{2}$ ]

For Yang Gui and the half a million people in Linxian County, receiving this greenlight was a critical step forward

Wei-Ning Xiang

wxiang@uncc.edu

Ying Chen

chenying@tjupdi.com

1 Tongji University, Shanghai, China

2 University of North Carolina at Charlotte, Charlotte, USA in their indomitable pursuit of the do-or-die water diversion project—building the Red Flag Canal to convey the

\footnotetext{
${ }^{1}$ [1] Throughout the article, the Pinyin translation of all Chinese people's names follows the official Chinese convention: family name + given name. The Pinyin translation of 杨贵 is therefore Yang Gui instead of Gui Yang [as is in Xiang (2020)]. [2] As the Party Secretary of Linxian County, Yang Gui was the top leader of the county [in Xiang (2020), he was incorrectly referred to as the county manager]. According to the Constitution of the Communist Party of China (The 19th National Congress of the Communist Party of China 2017), the Party's leading body in a jurisdiction (province, city, prefecture, county, town, etc.), an industrial or social organization (factory, company, school, hospital, etc.), a governmental agency, or a military unit is the Party committee elected by the Party congress in that entity (Ibid., Article 10). A Party committee elects a standing committee and delegates its own functions and powers to the standing committee when it is not in plenary session. Party secretaries and deputy Party secretaries are members of the standing committee (Ibid., Article 28). The Party Secretary (党委书记 in Chinese, an abbreviation of the First Secretary of the Party committee) is the "No. 1 leader" (第一 把手 in Chinese) of that entity ( $\mathrm{Li} 2009$, p. 9). Despite the organizational system of the party has evolved quite significantly since the founding of the party in 1921, this basic chain of command remains unchanged.

2 The original Chinese text is “(今天得知)山西方面同意(我们)引水 这个机会不可失, 错过机会, 林县人民可能将永远受缺水之苦。” (Wang and Sang 1995, p. 32; parentheses by the authors of this article).
} 


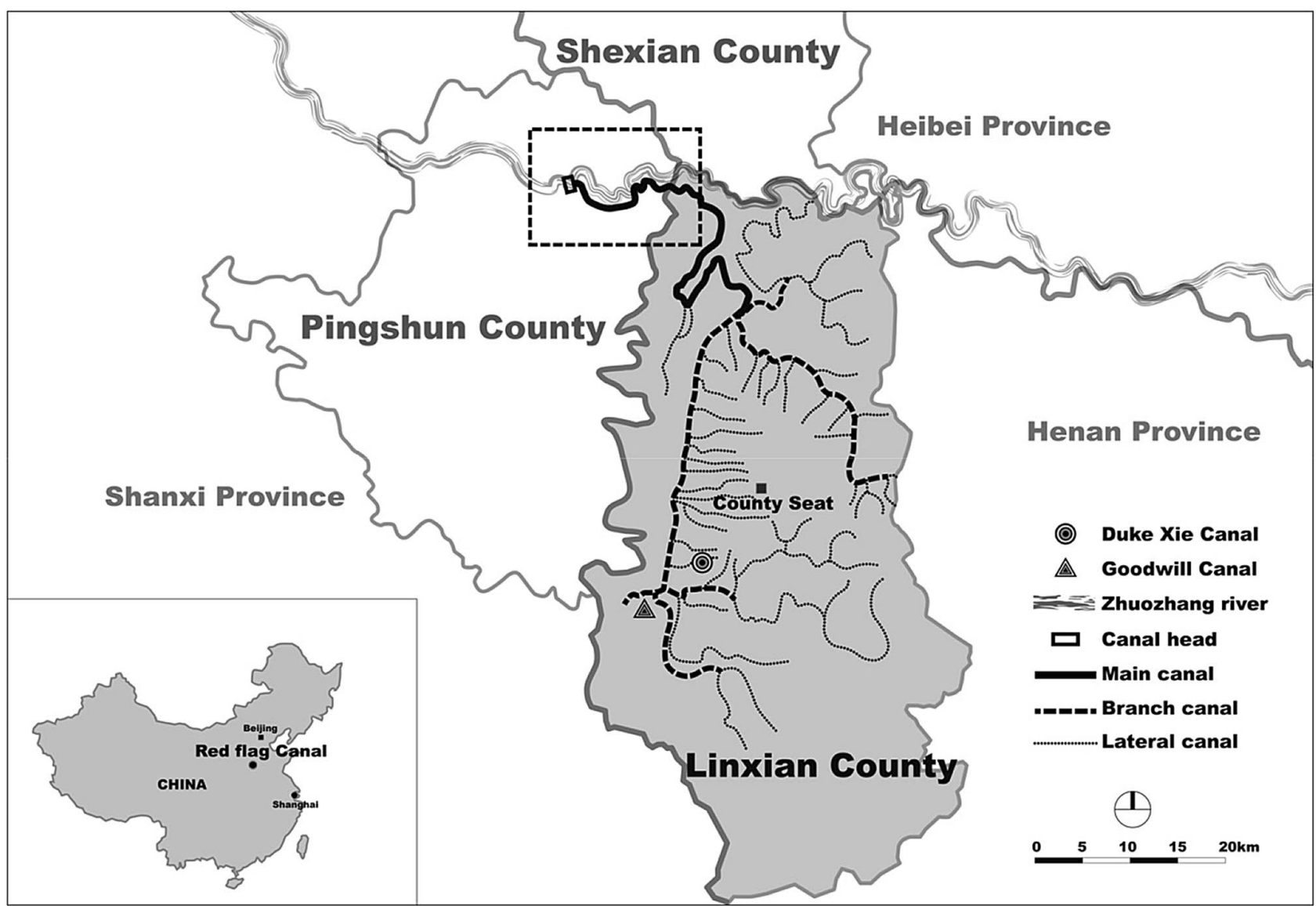

Fig. 1 The Red Flag Canal and its first 19-kilometer segment in Pingshun (in the dashed line box)

lifesaving water from the Zhuozhang River (浊漳河) to home [See Xiang (2020) for the genesis of this project].

How so?

As shown in Fig. 1, the eastbound Zhuozhang River flows through Pingshun County (平顺县) in Shanxi Province and continues along the border between Shexian County (涉县) in Hebei Province and Linxian County. But it is only in Pingshun where the riverbed is higher in elevation than the basin where Linxian is located. Since the water diversion canal, the Red Flag Canal, Yang Gui and the Linxian people planned to build is necessarily a gravity flow system-it conveys water and irrigates by means of gravity flow without pumping, the head of the canal must be built in Pingshun. The Linxian people therefore need the permission from the Shanxi provincial government to divert water from Pingshun and to use Pingshun's land for constructing the canal's first 19-kilometer segment, including a dam at the diversion point on the river (in the dashed line box in Fig. 1). Now, they got the momentous permission. It was indeed a huge step forward for their project (Hao et al. 2011, p. 127).

Acted expeditiously Yang Gui and his colleagues of the county's leadership team. They hosted a countywide project kickoff conference 4 days after on February 10 and led the Linxian people to officially get on with the project the next day on February 11, 1960 (Wang and Sang 1995, p. 33). Eight months later, after having had completed the canal's Pingshun segment (see the dashed line Box in Fig. 1), the Linxian project team moved on to the second phase of the project back in their home county (Ibid., pp. 56-58).

\section{A quick turnaround for a weighty permission}

Of the major antecedent events leading up to the crucial Shanxi permission, Chinese historians Wang Hongmin (王 宏民) and Sang Jilu (桑继禄) document the following chronology in their 1995 book A history of the Red Flag Canal (Wang and Sang 1995, pp. 26-31; English translation by the authors of this article).

January 24, 1960 (Sunday) 
Yang Gui wrote to Shi Xiangsheng (史向生), the Party Secretary of Henan Province, asking for a support letter;

\section{January 27 (Chinese's New Year's Eve)}

Shi Xiangsheng and Dai Suli (戴苏理), the Party Executive Secretary of Henan Province, wrote jointly a support letter to their counterparts in Shanxi Province一 the Party Secretary Tao Lujia (陶鲁笳) and the Party Executive Secretary Wang Qian (王谦);

\section{January 28 (Chinese New Year)}

The 3-day national celebration from January 28 to January $30^{3}$;

February 1 (the second workday after the national holiday)

Tao Lujia and Wang Qian convened a special meeting with Liu Kaiji (刘开基), the lieutenant governor of Henan Province. After hearing a presentation by two representatives from Linxian County, they decided to issue the permit;

February 3 (the second day after the greenlight decision) Wang Qian and Liu Kaiji replied to Shi Xiangsheng and Dai Suli on behalf of Tao Lujia and the Henan provincial government, acknowledging their decision ${ }^{4}$; upon receipt of the letter, Shi Xiangsheng and Dai Suli forwarded it to Yang Gui;

February 6 (the fifth day after the greenlight decision) Yang Gui received the forwarded letter, recorded this historical moment in his diary (see the preceding section).

Admittedly, a 2-week turnaround for such a weighty permission is extraordinarily quick, considering that the process involved a myriad of bureaucracies in two provinces and that communications in the 1960's China were primarily through snail mails and in-person meetings as the use of telephone was limited and long distance calls prohibitively expensive. Evidently, the leaders of the two provinces, Shi Xiangsheng and Tao Lujia, willingly made it happen by cutting through an otherwise long stretch of government red tape and shunning potentially protractive negotiations.

How come?

\footnotetext{
${ }^{3}$ In their 1995 book, Wang Hongmin and Sang Jilu do not provide the exact duration of the national holiday celebration. The three-day duration from January 28 to 30 was mentioned in the Chinese newspaper People's Daily published on February 3, 1960 (http://www. laoziliao.net/rmrb/1960-02-03-2\#238572, accessed March 31, 2020).

${ }^{4}$ In their 1995 book, Wang Hongmin and Sang Jilu thoughtfully include this letter and the letter by Shi Xiangsheng and Dai Suli (Wang and Sang 1995, p. 31).
}

\section{A no-brainer for Shi Xiangsheng}

For Shi Xiangsheng, supporting such a grassroots project that would benefit the people in his own province is a nobrainer. ${ }^{5}$ Besides providing foreseeable long-term benefits, he saw the canal, if completed quickly, could also help alleviate the ongoing hardships the Linxian people had been suffering from a severe draught since June $1959 .{ }^{6}$ No wonder he gave immediate support spontaneously the very first time he learnt the Red Flag Canal project idea from Yang Gui in September 1959 (Hao et al. 2011, p. 123). That was just 3 months after Yang Gui came up with the bold idea of building an irrigation canal to bring the lifesaving water in the Zhuozhang River to home (Xiang 2020, pp. 108-109).

But why was Tao Lujia so willing and swift to support a project that would divert water from his home province to benefit the people in a neighbor province?

\section{What did Tao Lujia have to say about his motivations?}

Almost 40 year after the instance, Tao Lujia and Yang Gui met on August 10, 1999 (Fig. 2). Reflecting on his motivations for the 1960 greenlight decision, Tao Lujia shared with Yang Gui how his personal life-work experience in Linxian and sympathetic affection for the people impelled him to act forthright on the permission request and beyond (Hao et al. 2011, pp. 127-128). The following two passages from his reflections are instructive and noteworthy as they offer hints of why he was so willing and swift to support the project in 1960 (ibid., pp. 127-128; English translation, parentheses, italics, and subsection titles all by the authors of this article).

\footnotetext{
${ }^{5}$ It is indeed a grassroots project by the Linxian people. According to Xiang (2020, pp. 106-107), the Canal's planning, design, construction, project management, and institutional arrangements were all undertaken and completed by the Linxian people themselves with their own diligent efforts, local talents, and available resources. Most of the project expenditures (85\%) was funded locally. The technical support and financial assistance from the provincial and national governments helped improve the project quality and efficiency significantly. They, however, did not come until 1964, the fifth year into the project.

6 "To the Linxian people, 1959 is a year of misfortune. A brutal, injurious drought forcefully interrupted their routine time-sensitive practice of summer crop planting in early June; the concomitant severe shortage of drinking water supplies presented yet another lifethreatening hardship." (Xiang 2020, p. 107) For more about these and other hardships caused by the draught and how Yang Gui and the Linxian people coped, see Xiang (2020, pp. 107-109).
} 


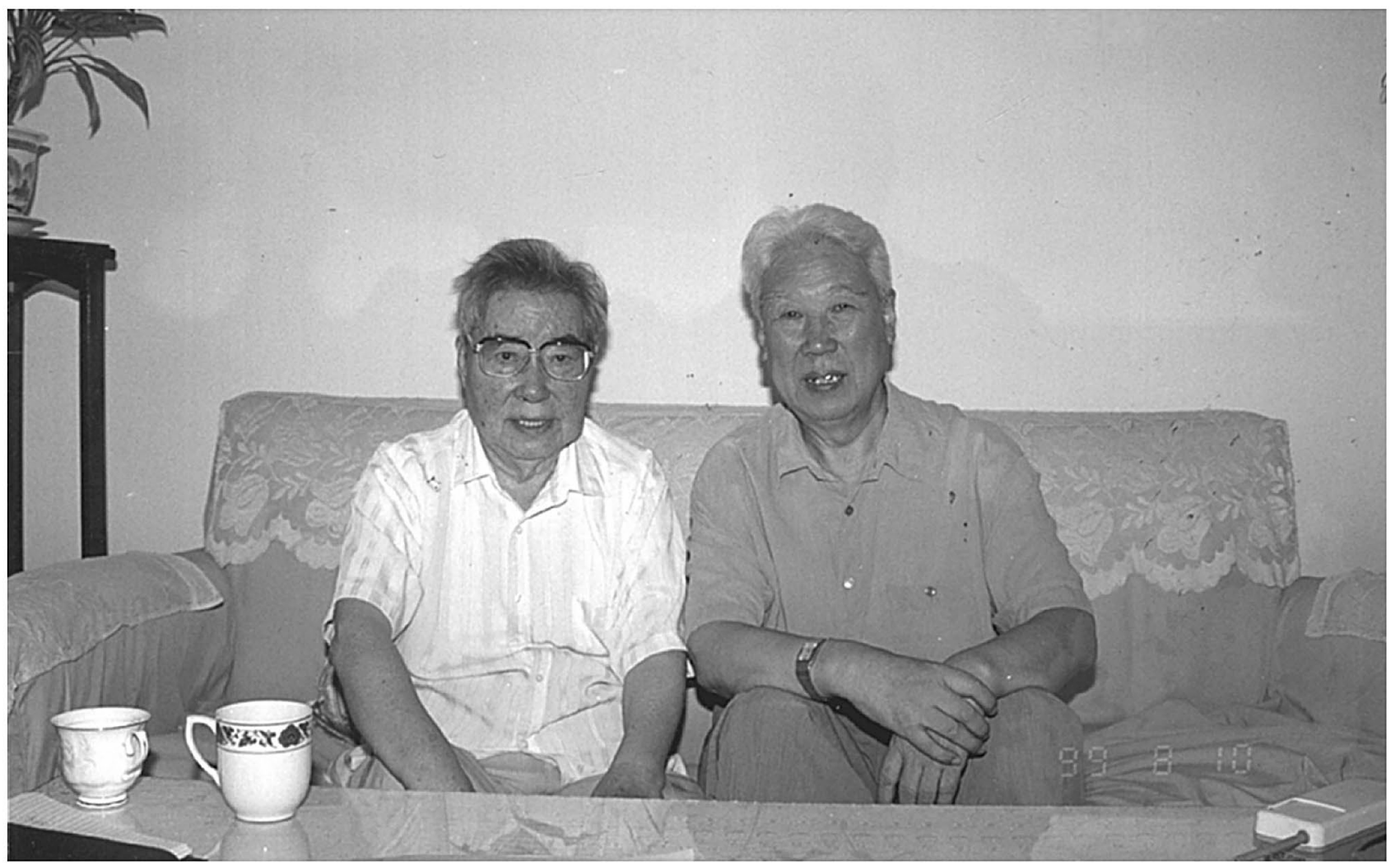

Fig. 2 Tao Lujia (left) and Yang Gui met on August 10, 1999 (source: Hao et al. 2011, p. 126; use with permission)

\subsection{A window of opportunity for fulfilling a long-held desire to help}

I (Tao Lujia) lived in Linxian for two years while working at the headquarters of the Fifth Prefecture Party committee. That was (in the mid-1940s) at the end of the 14-year war of resistance against Japanese aggression and the beginning of the civil war. I therefore knew firsthand the hardships of water shortage the Linxian people had been suffering. ... (After having had greenlighted the Red Flag Canal project on February 1, 1960), I also told members of the Party committees of both Pingshun County and the Southeast Shanxi Prefecture that we must support Linxian people's do-or-die endeavor unconditionally. ${ }^{7}$

7 [1] The original Chinese text is “战争年代,太行五地委驻在林县, 当时我在地委工作,知道林县缺水的苦难。……我曾给晋东南地 委的同志说要支持红旗渠,平顺县委领导来省里开会, 我也给他们 说, 林县有什么困难一定要支持。”(Hao et al 2011, pp. 127-128) [2] In the $1940 \mathrm{~s}$, there were two consecutive wars in China. The first was the continuing 14-year war of resistance against Japanese aggression (1931-1945) [Sun 2017; Sino Japanese wars 2018], also referred to as "the Second Sino-Japanese War" by some historians outside China (for example, Sino Japanese wars 2018). The second
Reading between the lines, it appears that he regarded supporting the Red Flag Canal project to be a way of fulfilling a personal desire he had held since the mid-1940s. More specifically, (1) he had a long-held desire to help assuage the suffering of the Linxian people from the hardships of water shortage; (2) the desire stemmed from his firsthand experience suffering the hardships together with the Linxian people during wartime in the mid-1940s; (3) he had been longing for opportunities to fulfill his desire; (4) when the opportunity finally emerged in 1960, he seized it to the best of his ability and did everything possible in his power to help—as the top leader of Shanxi Province, not only did he

Footnote 7 (continued)

was the Chinese civil war (1945-1949) between the Nationalists and the Communists (Dobbs 2009). [3] In 1960, Pingshun was a constituent county of the Southeast Shanxi Prefecture (Hao et al. 2011, p. 127). The support from both Pingshun and the Prefecture was critically important to the Red Flag Canal project because, as explained in Sect. 1 and shown in Fig. 1, the first 19-kilometer segment of the Red Flag Canal was to be constructed on the Pingshun soil. 
swiftly give the much-needed greenlight to the Red Flag Canal project, but also voluntarily went the extra mile, after the greenlight decision, to make sure his subordinates do their best to help.

\subsection{Fulfilling the desire to help: a source of happiness and gratitude}

I (Tao Lujia) admire so much the great service and lasting good you Yang Gui brought to the Linxian people through the Red Flag Canal project. In retrospect, I originally thought what you planned to build was just a small canal that would bring back home the Zhuozhang River water for drinking (and for alleviating the hardships caused by the 1959 draught). It really astonished me later that the "small canal" turned out to be such a great man-made river, so much so that even Premier Zhou Enlai praised it a miracle in the modern-day China! $!^{8}$

Reading between these lines, one can feel a strong sense of double happiness and gratitude resulting from the fulfillment of the desire to help. ${ }^{9} \mathrm{He}$ was happy for the Linxian people as their suffering from the hardships of water shortage had been effectively mitigated through the Red Flag Canal project; he was happy for himself as his longheld desire to help was finally fulfilled through his 1960

\footnotetext{
${ }^{8}$ [1] The original Chinese text is “我以为你杨贵引漳入林,也不过 是修条小渠解决吃水, 没想到你竟然修了那么大一条人造天河, 被 周总理称为新中国的奇迹! 你为林县人民办了件大好事。“(Hao et al 2011, pp. 127-128) [2] The phrase "great man-made river" (all in lower case) is used to translate the Chinese phrase “那么大一条人 造天河” in its own right. We are aware that the phrase "Great ManMade River" has been used since 1983 to denote an underground pipeline network that transports fresh fossil water to the coast of Libya for agricultural, domestic, and industrial uses [For related references, see Gearon (2011) and The Editors of Encyclopedia Britannica (2019), among others]. There is, however, an amazing commonality between the two-both the "great man-made river" (the Red Flag Canal) and the "Great Man-Made River" (the underground pipeline network in Libya), have been praised, respectively, by various people as "the Eighth Wonder of the World" (The Editors of Encyclopedia Britannica 2019; Wang and Sang 1995, p. 5). [3] In 1971, the then Chinese Premier Zhou Enlai [周恩来 (1898-1976)] said: “There are two miracles of engineering in the modern-day China that people created with self-reliance and diligence, one is the Nanjing Yangtze River Bridge, and the other the Red Flag Canal in Linxian County." (Xiang 2020, p. 105) [4] More about this "socio-ecological practice miracle," see Xiang (2020).

9 The term "double happiness" here refers to the joy Tao Lujia expressed for both the Linxian people and himself and thus literally means "happiness plus happiness." The use of the term is inspired by the Chinese character 鿷 and the double-happiness connotation it carries. 喜 is a compound of 喜 and 喜, two identical characters, each of which means happiness. In its ordinary use in Chinese tradition, however, double happiness (喜) is used only as an ornamental design motif associated with weddings.
}

greenlight decision which contributed to the Red Flag Canal project in a big way (see Sect. 1 of this article). And with that, he was grateful to Yang Gui both for the outstanding leadership in the life-changing, miracle-making project and for providing the opportunity he (Tao Lujia) had been longing for to help. In a nutshell, he was delightful that his 1960 greenlight decision turned out to be both prosocial and self-rewarding - not only did it help bring about great socio-ecological benefits, but also boosted his own mental well-being. ${ }^{10}$

\section{Further questions for more systematic, deeper understanding}

The two passages quoted above are informative about Tao Lujia's motivations for the 1960 greenlight decision. They are provocative as well-begging further questions that prompt new lines of inquiry for more systematic, deeper understanding.

Three such questions point directly to an undisclosed mental-behavioral process (i.e., thinking-acting process); Tao Lujia would have gone through that impelled him to proceed willingly and swiftly toward the greenlight decision.

What personal mental-behavioral process would Tao Lujia have gone through from the mid-1940s to 1960 that enabled him, a person with many high-level leadership responsibilities, to first develop a specific desire of helping the people in a particular locale, then to keep it alive and strong for a long period of time, and eventually to fulfill it when time was ripe in 1960 ?

\footnotetext{
$\overline{10} \mathrm{He}$ would also be happy and grateful to hear that constructing the canal's first 19-kilometer segment on the Pingshun soil benefitted the Pingshun people as well, especially those who lived along the canal. Thanks to the compassionate and collaborative leaderships in both Pingshun and Linxian, mutually beneficial arrangements were made between the two counties and coded later in a 1962 agreement $(\mathrm{Li}$ et al. 2004, p. 121, p. 178; Wang and Sang 1995, pp. 148-150). There are three key provisions in the agreement (see Appendix for a replica and translation of the agreement). (1) Linxian is granted a permanent easement to use a 19-kilometer-long, 8-meter-wide swath of Pingshun land for canal purpose; (2) villages of the two Pingshun communes along the canal are entitled to use the canal water for drinking, irrigation, and powering water mills; (3) Linxian makes a onetime payment to compensate the two people's communes in Pingshun County for their loss of land and properties to the construction of the Red Flag Canal. The grassroots, goodwill agreement was initiated by Yang Gui (Hao et al. 2011, p. 139) and ratified by 17 government agencies from the two counties (Wang and Sang 1995, pp. 148-150). Was Tao Lujia aware of this? He did not mention in his published books that we could find (Tao 1991, 1993, 2003), nor could we find any document to prove. But nonetheless, this would bring him more happiness and gratitude beyond doubt.
} 
What kind of leadership role did Tao Lujia choose to play that helped impel him to go through such a lasting mental-behavioral process and allowed him to benefit from serving others?

How come he exercised this kind of leadership so well?

Answers to these questions are certainly not readily visible to the naked eye; but, as shown in our second article (Chen and Xiang 2020) published in this journal, they can be found with the assistance of a cognitive instrument-a lens of compassion practice.

Let us proceed.

Acknowledgements We are indebted to the following individuals who provided valuable assistance during the preparation of this article: John Forester (Cornell University, USA); Gao Wei [(高伟) South China Agriculture University, Guangzhou, China], Li Yiman [(李沂 曼) South China University of Technology, Guangzhou, China]; Kristen Banaszak, Erika Boardman, and Reese Manceaux (both with the Atkins Library, University of North Carolina at Charlotte, USA); Wang Yanping [(王燕萍) Corpus of Chinese Communist Party History, Beijing]; Shen Ning [(沈宁) (Hebei University of Engineering, Handan, China)]; Wang Fuguang [(王福光) The Shanxi Province Party History Research Institute, Taiyuan, China]; Hao Jiansheng [(郝建生), Anyang Daily, Anyang, China].

\section{Appendix 1: Historical agreement in 1962 between two counties in two provinces}

In the Red Flag Canal Museum in Linzhou City [林州, formerly Linxian County (林县)], Henan Province, China, there is a replica of a 1962 settlement (Fig. 3). ${ }^{11}$ The agreement was reached between the then Linxian County and its neighbor Pingshun County in Shanxi Province on two issues pertaining to water diversion from the Zhuozhang River in Pingshun to Linxian (Li et al. 2004, p. 121): (1) Linxian's use of Pingshun's land for constructing the canal's first 19-km segment, including a diversion dam (shown in the dashed line box in Fig. 1); (2) Pingshun's use of the canal water once the canal is built.

There are three key provisions in the agreement (Wang and Sang 1995, pp. 148-150; English translation and provisions' titles by the authors of this article) ${ }^{12}$ :

\footnotetext{
11 On January 24, 1994, Linxian County became Linzhou City [Hao et al 2011, p. 393]. In the literature about the history of the Red Flag Canal, however, authors continue using the historical name "Linxian County." Like the first article in the mini-series on the canal (Xiang 2020), this article follows that convention for consistency and uses the present name "Linzhou City" only when necessary.

12 The original Chinese text is “《林县、平顺两县双方商讨确定红 旗渠工程使用权的协议书》(节选) '第一,根据国家建设征用土地 办法第七条规定,征用土地的补偿费以最近两年至四年的定产量 的总值为标准, 对占用平顺县人民群众的土地、山坡、房屋、树 木等一切财产, 林县于1961年5月10日全部作价赔款三十六万四千
}

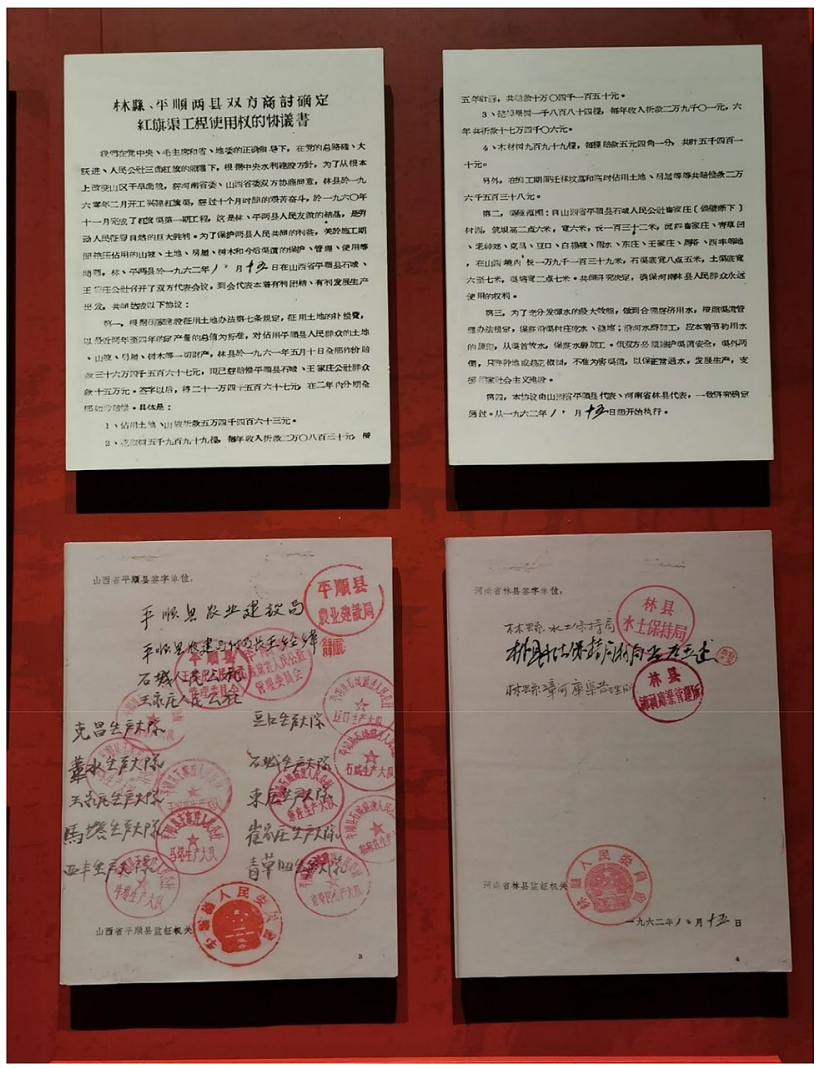

Fig. 3 A replica of the 1962 agreement between Linxian County and Pingshun County in the Red Flag Canal Museum in Linzhou City (Taken in situ by Wei-Ning Xiang, July 14, 2019)

\section{A permanent easement ${ }^{13}$}

\section{Footnote 12 (continued)}

五百六十七元, 现已经赔偿平顺县石城、王家庄公社群众十五万 元。签字以后, 将二十一万四千五百六十七元，在二年内全部如数 赔偿。……第二,渠线范围: 自山西省平顺县石城人民公社崔家庄 (候壁断下)村西, 筑坝高2.6米、宽6米、长132米,(渠线)流经...... 在山西境内长19139米, 石渠底宽8.5米, 土渠底宽6-7米,渠墙宽 2.7 米。共同研究决定, 确保河南省林县人民群众永远使用的权利。 第三,为了充分发挥水的最大效能,做到合理经济用水, 按照渠道管 理办法规定,保证沿渠村庄吃水、浇地;沿河水磨加工,应本着节 约用水原则, 从渠首放水, 保证水磨加工。但双方必须维护渠道安 全,渠外两侧, 只许种地或栽花椒树, 不准危害渠道, 以保证正常通 水, 发展生产, 支援国家社会主义建设。”(Wang and Sang 1995, pp. 148-149).

${ }^{13}$ The Chinese legal concept of easement (地役权) was established 45 years later in The Property Law of the People's Republic of China. Passed in the National People's Congress on March 6th, 2007, the Property Law became effective October 1 the same year. The term easement is used here to help readers to appreciate the historical significance of this provision through the lens of a contemporary concept. This is an example of moral improvisation in which practitioners circumspectly exercised ecophronesis to make, and act well upon, right choices in a specific context of socio-ecological practice [for an account of ecophronesis-ecological practical wisdom, see Xiang (2016)]. 
The canal's diversion dam is located on the Zhuozhang River near the Cuijiazhuang Village in Pingshun County; From this diversion point, the canal extends to Linxian County through a 19-km-long, 8-m-wide swath of land in Pingshun County; Both counties agree that Linxian County has the permanent right to use this swath of land for the canal purpose.

\section{The right to use canal water}

Once the canal is built, villages of the two Pingshun communes along the canal are entitled to use the canal water for drinking, irrigation, and powering water mills. Both counties have the responsibility to maintain the canal's normal operations and safety.

\section{A onetime compensation payment}

Linxian County will pay Pingshun County a total of 364,560 RMB to compensate the two people's communes in Pingshun County for their loss of land and properties to the construction of the Red Flag Canal.

This agreement was ratified by 17 governmental agencies from the two counties in two provinces (see the stamps on the two bottom pages of the replicate in Fig. 3).

\section{References}

Chen Y, Xiang W-N (2020) Why was Tao Lujia so willing and swift to greenlight the Red Flag Canal Project in 1960? New insights via a lens of compassion practice. Socio-Ecol Pract Res. https://doi. org/10.1007/s42532-020-00061-4

Dobbs CM (2009) Civil war 1945-1949. In: Song Y (ed) Encyclopedia of Chinese American relations [Online]. Jefferson, McFarland. https://go.openathens.net/redirector/uncc.edu?url=https $\% 3 \mathrm{~A} \% 2 \mathrm{~F} \% 2 \mathrm{Fsearch} . c r e d o r e f e r e n c e . c o m \% 2 \mathrm{Fcontent} \% 2 \mathrm{Fent}$ ry\%2Fmcfcham\%2Fcivil_war_1945_1949\%2F0\%3FinstitutionId \%3D5899. Accessed Mar 312020

Gearon E (2011) Wales in the dessert. In: Gearon E (ed) The Sahara: a cultural history. Oxford University Press, Oxford, pp 3-10

Hao J, Yang Z, Li Y (2011) Yang Gui and the Red Flag Canal. Central Compilation and Translation Press, Beijing (in Chinese) [ 郝建 生,杨增和,李永生 (2011)《杨贵与红旗渠》, 中央编译出版社, 北京]

Li C (2009) Intra-party democracy in China: should we take it seriously? China Leadersh Monitor 30(4):1-14

Li L, Pei S, Li L, Yang W (2004) China's Red Flag Canal: its resource background and institutional arrangements. Henan People's Press, Zhengzhou (in Chinese) [李露亮, 裴少峰, 李露钢, 杨武中 (2004) 《中国红旗渠:资源背景与制度安排》, 河南人民出版社, 郑州]

Sino Japanese wars (2018) In: Helicon (Ed.) The Hutchinson unabridged encyclopedia with atlas and weather guide [Online]. Abington, Helicon. https://go.openathens.net/redirector/uncc. edu?url=https $\% 3 \mathrm{~A} \% 2 \mathrm{~F} \% 2 \mathrm{Fsearch}$. credoreference.com $\% 2 \mathrm{Fcon}$ tent $\% 2$ Fentry $\% 2$ Fheliconhe $\% 2$ Fsino_japanese_wars $\% 2$ F0\%3Fins titutionId\%3D5899. Accessed Mar 312020

Sun J (2017) 14-year war of resistance against Japanese aggression a consensus among Chinese historians. People's
Daily Online, 17:24, January 11, 2017. http://en.people.cn/ n3/2017/0111/c90000-9165703.html. Accessed 30 Mar 2020

Tao L (1991) Chairman Mao brought us golden dew of ideas: a recollection of the Fenhe Reservoir project. In: Tao L (ed) (1993) A memoir of Chairman Mao by a provincial Party Secretary, 97-107. Shanxi People's Press, Taiyuan (in Chinese) [陶鲁笳 (1991) 毛主席给我们送来了及时雨一回忆汾河水库的建设,收 录在:陶鲁笳 (1993) 《一个省委书记回忆毛主席》, 山西人民 出版社,太原, 第97-107页]

Tao L (1993) A memoir of Chairman Mao by a provincial party secretary. Shanxi People's Press, Taiyuan (in Chinese) [陶鲁笳 (1993) 《一个省委书记回忆毛主席》, 山西人民出版社,太原]

Tao L (2003) Chairman Mao taught us how to be a provincial party secretary. Central Party Literature Press, Beijing (in Chinese) [ 陶鲁笳 (2003) 《毛主席教我们当省委书记》，中央文献出版 社,北京]

The 19th National Congress of the Communist Party of China (2017) Constitution of Communist Party of China, revised and adopted at the 19th National Congress of the Communist Party of China on October 24, 2017. Xinhua News Agency. http://www.xinhuanet.com/english/ special/2017-11/03/c_136725945.htm. Accessed 1 Apr 2020

The Editors of Encyclopedia Britannica (2019) Great man-made river. Encyclopedia Britannica, Encyclopedia Britannica, Inc. https://www. britannica.com/topic/Great-Man-Made-River. Accessed 31 Mar 2020

Wang H, Sang J (1995) A history of the Red Flag Canal. SDX Joint Publishing Company, Beijing (in Chinese) [王宏民,桑继禄 (1995)《红旗渠志》, 北京三联书店,北京]

Xiang W-N (2016) Ecophronesis: the ecological practical wisdom for and from ecological practice. Landsc Urban Plan 155:53-60

Xiang W-N (2020) The Red Flag Canal: a socio-ecological practice miracle from serendipity, through impossibility, to reality. SocioEcol Pract Res 2(1):105-110. https://doi.org/10.1007/s42532-01900037-z

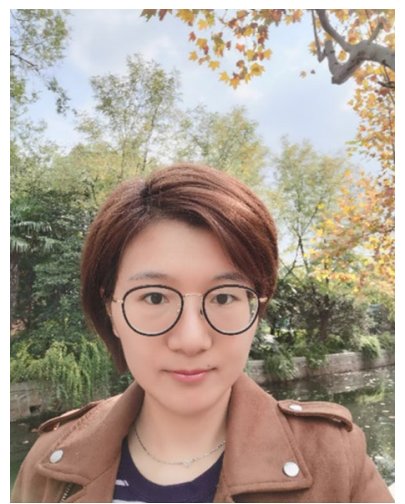

Ying Chen Ying Chen is on the staff of the College of Architecture and Urban Planning, Tongji University, Shanghai, China. A Ph.D. candidate in School of Ecological and Environmental Sciences at East China Normal University, she received a master's degree in biology from the University of Mississippi, USA.

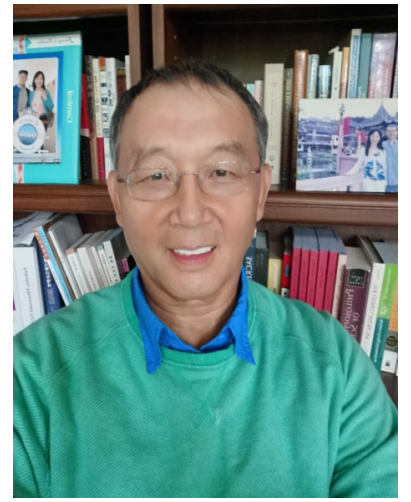

Wei-Ning Xiang is a Professor of Geography and Earth Sciences at the University of North Carolina at Charlotte, USA (1990-present); the former co-editor-inchief of Landscape and Urban Planning (2011-2018), he is the founding editor-in-chief of Socio-Ecological Practice Research (SEPR). 